\title{
Muğla Orman Bölge Müdürlüğü idari sınırlarında yayılış gösteren endemik bitki taksonlarının güncel durumu
}

Current status of endemic plant taxa in the administrative boundaries of Muğla Regional Directorate of Forestry

Hafize Handan ÖNER ${ }^{1}$

Nihal ÖZEL ${ }^{1}$

Nuran ALTUN ${ }^{1}$

Yüksel YANMADIK ${ }^{2}$

${ }^{1}$ Ege Ormancılık Araştırma Enstitüsü Müdürlüğ̈̈, İzmir

${ }^{2}$ Orman Genel Müdürlüğ̈̈,Muğla Orman Bölge Müdürlüğü, Muğla

Sorumlu yazar (Corresponding author) Hafize Handan ÖNER

hhnd_1971@yahoo.com

Geliş tarihi (Received)

16.09.2020

Kabul Tarihi (Accepted)

07.02.2021

Sorumlu editör (Corresponding editor) Ali KAVGACI

alikavgaci1977@yahoo.com

Atıf (To cite this article): Öner, H, Özel, N, Altun, N , Yanmadık, Y . (2021). Muğla Orman Bölge Müdürlüğü idari sınırlarında yayılış gösteren endemik bitki taksonlarının güncel durumu . Ormancilık Araştırma Dergisi , 8 (1) , 97-107. DOI: https://doi.org/10.17568/ogmoad.792035

\section{Öz}

Bu araştırmada Muğla Orman Bölge Müdürlüğü (Muğla OBM) idari sınırları içinde yayılış gösteren endemik bitki taksonlarının güncel durumunun belirlenmesi amaçlanmıştır. Bu doğrultuda öncelikle ilgili literatürler taranarak çalışma alanında kaydedilen endemik bitki taksonları belirlenmiş ve listelenmiştir. Sonrasında çalışma tüm alanda tarama olarak gerçekleştirilmiştir. Arazi çalışmaları sırasında; söz konusu taksonların bulunduğu noktaların koordinatları, yükselti, anakaya, habitat ve mevkii özellikleri kaydedilmiştir.

Çalışma sonucunda, Muğla OBM sınırları içinde yayılış gösteren 39 familya ve 132 cinse mensup toplam 368 adet endemik vasküler bitki taksonu belirlenmiştir. Belirlenen bu taksonların IUCN durumları ve CITES kapsamları ayrıca incelenmiştir. Buna göre, çalışma alanında tespit edilen endemik taksonların 321'inin bir IUCN değerine sahip olduğu ve 2 adedinin ise CITES kapsamında yer aldığı görülmüştür. Ayrıca bu çalışma sonucunda 29 familya ve 49 cinse mensup olmak üzere, toplam olarak 83 adet endemiklikten çıkarılan takson kaydedilmiştir.

Anahtar Kelimeler: Muğla, flora, endemik, IUCN, CITES

\section{Abstract}

In this study, it is aimed to determine the current status of endemic plant taxa which are spreading within the administrative boundaries of Muğla Regional Directorate of Forestry (RDF). In this respect, firstly, the related literature was searched and endemic plant taxa recorded in the study area were identified and listed. The study was conducted as a screening in the whole area. During field studies; coordinates, altitude, bedrock, habitat and location characteristics of the points in question were recorded.

As a result of the work carried out in the administrative boundaries of the Mugla RDF, 39 family and 132 genus, a total of 368 endemic vascular plant taxa were determined. The IUCN status and CITES coverage of these taxa were also investigated. According to this, 321 of the endemic taxa determined in the study area have an IUCN value. Two of these taxa are covered by CITES. In addition in this study, 29 family and 49 genus, a total of 83 vascular plant taxa which no longer endemic were determined.

Key words: Muğla, flora, endemic, IUCN, CITES 


\section{Giriş}

Kuzey yarımkürede $36^{\circ}-42^{\circ}$ kuzey enlemleri ile $26^{\circ}-45^{\circ}$ doğu boylamları arasında ve orta enlem kuşağında yer alan Türkiye'nin topografya ve iklimindeki farklılıklar biyolojik çeşitliliğine yansımaktadır. Deniz seviyesinden 2.000 metre (m) ve üstü yüksekliğe sahip dağları, doğal yaşam alanlarındaki çeşitlilik, ılıman iklim kuşağında olması, kısa mesafelerde ortaya çıkan toprak ve jeolojik yapısındaki farklılıklar, coğrafik konumunun getirdiği üç farklı flora bölgesinin kesişim noktası olması ve Güneybatı Asya ile Güney Avrupa arasında bitki göçlerinde köprü görevi görmesi biyolojik çeşitlilik açısından Türkiye'nin "Küçük Asya" olarak tanımlanmasını sağlamıştır (Gemici, 1999; Eken ark., 2006; Akkemik, 2014).

Biyolojik çeşitlilik; karasal, sucul ve bu ikisi arasında yer alan kıyısal ekosistemler ile bu ekosistemleri oluşturan daha küçük ekolojik birimlerde yaşayan tüm organizmaların oluşturduğu ve aynı zamanda ekolojik ve genetik çeşitliliği de ifade eden bir kavramdır (Gemici, 1999). Gülsoy ve Özkan (2008)'a göre biyolojik çeşitlilik gen, tür ve ekosistem çeşitliliği olmakla birlikte, Geray ve Akesen (2001) buna süreç çeşitliliğini ilave etmiştir.

Endemik bitki terimi ise sınırlı yayılışa sahip, büyük çoğunlukla yeryüzünün sadece bir bölgesinde veya daha küçük alanlarında yayılış gösteren türleri ifade eder (Gemici, 2001). Çoğu zaman da ait oldukları ülkeler için kullanılan bir ifadedir.

Ülkemizde birçok canlı türünün "tek nokta endemiği” bulunmaktadır. Bu türler, yeryüzünde sadece Türkiye'de bir noktada yaşamaktadır ve bu türlerin büyük bir kısmını bitkiler (421 tür) oluşturur. Söz konusu türlerin 394 tanesi (\%87) ülke çapında belirlenen 125 Önemli Doğa Alanı'nın (ÖDA) içinde yayılış gösterirken, geri kalan 57 tür (\%13) ise henüz bir ÖDA sınırı içine alınmamıştır (Eken ve ark., 2006).

Genel olarak ifade etmek gerekirse, Türkiye her on günde yeni bir bitki taksonunun keşfedildiği, flora zenginliği açıkça ortada olan bir doğal yaşam alanıdır. Bu topraklarda yayılış gösteren tohumlu bitkilere ait en son veriler "Türkiye Bitkileri Listesi (Damarlı Bitkiler)" (Güner ve ark., 2012) eserinde; 11.707 tür, tür altı, doğallaşmış, egzotik ve kültür edilen takson olduğu doğrultusundadır. Esere göre Türkiye florasının endemik tür sayısı 3.035 ve endemizm oran1 \%31,12'dir (Ekim, 2014).

Nesli Tehlike Altında Olan Yabani Hayvan ve Bitki Türlerinin Uluslararası Ticaretine İlişkin Sözleşme (CITES: The Convention on Internati- onal Trade in Endangered Species of Wild Fauna and Flora) yabani hayvan ve bitki türlerinin canlı ve ölü örnekleri ile bunların kolayca tanınabilen parçaları ile türevlerinin sözleşmeye taraf ülkeler arasındaki ithalatını, ihracatını, reeksportunu ve denizden girişini kısacası, uluslararası ticaretini; temeli izin ve belgelere dayanan ve ancak sözleşmede belirtilen şartların yerine getirilmesi halinde bu izin ve belgelerin verilmesini öngören uluslararası bir düzenlemedir. CITES Sözleşmesinin amac1; yabani hayvan ve bitki türlerinin ticaretinde bu canlıların yaşamlarının tehlikeye girmesini önlemektir (URL 1).

Uluslararası Doğayı Koruma Birliği (IUCN: International Union for Conservation of Nature) ve ilgili diğer birlik ve komiteler son yıllarda yeryüzünde yayılış gösteren bitki türlerinin, öncelikle de çoğunluğu dar ve sınırlı yayılışa sahip endemik türlerin, korunmaları hakkında olabildiğince ciddi çalışmalar yapmaktadır. Bir bitkinin tehdit altında olup olmadığı floristik çalışmalar ve halktan gelen deneyim ve gözlemler sonucunda elde edilen veriler 1 şı̆̆ında belirlenmektedir. Yetiştiği ortamlardaki popülasyonlarında azalma veya bulunduğu yaşam alanı yok olma tehlikesi altında olan türlerin varlıklarının sürekliliği tehdit altında demektir. Söz konusu türlerin uluslararası kapsamda tehlike ulamlarından hangisine ait oldukları saptanarak alınacak önlemlerde öncelik yüksek baskı ve nesli kaybolma tehlikesi altında olanlara verilmektedir. IUCN kırmızı liste ulamları ve ölçütleri; IUCN Konseyi tarafından 1994'te onaylanmasından beri uluslararası kabul görmüş, gerek IUCN gerekse pek çok hükümet ve kuruluş tarafından yayımlar ve listelerde kullanılan en kapsamlı "Küresel Koruma Durumu" dökümüdür. Bu çalışmada belirlenen taksonların içinde bulundukları ulamlar "The IUCN Red List of Threatened Species" resmî sitesi (URL 2), "Tehdit Altında Bitki Türleri” sitesi ve "Türkiye Bitkileri Kırmızı Kitabı" (Ekim ve ark., 2000) karşılaştırılarak belirlenmiş ve değerlendirilmiştir.

$\mathrm{Bu}$ araştırmada; Muğla OBM sınırları içinde yayılış gösteren endemik bitki taksonlarının güncel durumları (Öner ve ark., 2018), IUCN tehlike ulamları ve CITES kapsamlarının tespit edilmesi amaçlanmıştır.

\section{Materyal ve Yöntem}

\subsection{Materyal}

Çalışmanın materyalini çalışma alanı sınırlarında yayılış gösteren endemik vasküler bitki taksonları oluşturmaktadır. 


\subsubsection{Araştırma alanının tanıtımı}

Çalışma alanı Muğla OBM ile sınırlı olup Muğla ve Aydın illerini kapsamaktadır. Coğrafi olarak Güneybatı Anadolu'da yer alan Bölge Müdürlüğü; 12 adet Orman İşletme Müdürlüğü ve 74 adet Orman İşletme Şefliği olarak teşkilatlandırılmıştır (Şekil 1). Çalışma alanı Davis (1965)'in kullandığ 1 karelaj ağ1 sistemine göre $\mathrm{C} 1, \mathrm{C} 2$ ve B2 kareleri içinde yer almaktadir.

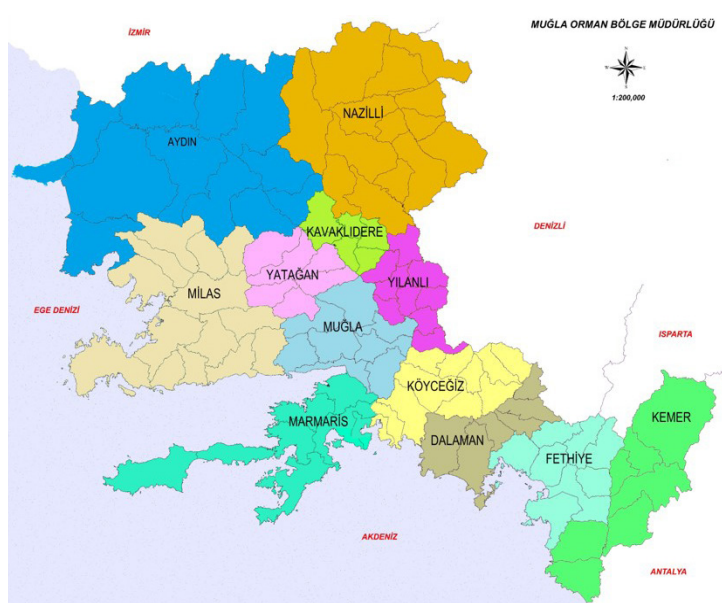

Şekil 1. Muğla OBM, Orman İşletme Müdürlükleri haritas1 (URL 3)

Figure 1. Muğla Regional Directorate of Forestry, Operation Directorates map (URL 3)

Bölge Müdürlüğünün toplam orman alanı 1.158.925 hektar (ha) olup 327.606 ha'1 Aydın ve 831.319 ha'1 Muğla illerinde yer almaktadır. Ormansız alan toplamının 2.0512.212 ha olduğu bölgede ormanlık alan oranı yaklaşık \%36'dır (URL 4).

Çalışma alanında; 10 Önemli Bitki Alanı, 18 Önemli Doğa Alanı, 18 Bitki Çeşitlilik Merkezi, 5 Özel Çevre Koruma Bölgesi ve 2 Sicak Nokta bulunmaktadır (Özhatay ve ark., 2003; URL 5; Eken ve ark., 2006).

\subsubsection{Araştırma alanının jeolojisi}

Çalışma alanının yer aldığ 1 Batı Anadolu'da paleocoğrafik kuşaklarını Ersoy (1990), en kuzeyde İzmir-Ankara Zonu onun güneyinde örtü kuşağ1 ile birlikte Menderes Masifi, Batı Toros Teknesi, Bat1 Toros Platformu, Bey Dağları Otokton Zonu ve en güneyde Antalya Napları Zonu olarak belirtir.

Kuzeyden güneye İzmir-Ankara Zonu (IAZ), Menderes Masifi (MM) ve onu saran Menderes Örtü Kuşağı (CMZ), Batı Toros Teknesi (BTT), Batı Toros Platformu (BTP), Bey Dağları Otokton Zonu (BOZ) ve Antalya Napları Zonu (ANZ) olarak) (Şekil 2) sıralanmıştır (Ersoy, 1990).

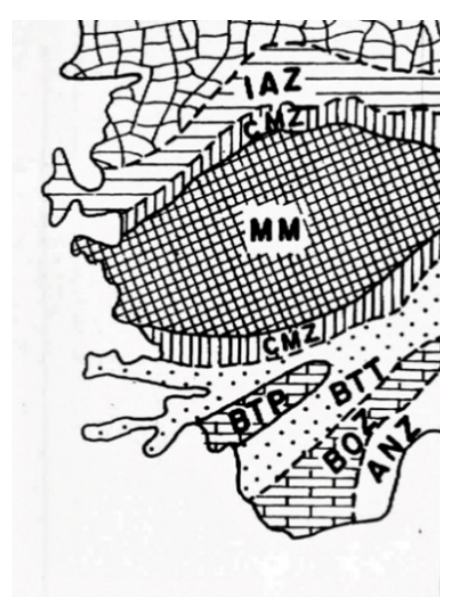

Şekil 2. Batı Türkiye'nin Paleocografik Kușakları (Ersoy,1990)

Figure 2. The paleogeographical zones of The Western, Turkey (Ersoy, 1990)

Anadolu'nun güneybatısında yer alan çalışma alan1 Menderes Masifi'nin güneyi ve Toros sisteminin batı ucunu içine almaktadır.

\subsubsection{Araștırma alanının iklimi}

Çalışma alanının iklim özelliklerinin belirlenmesi amacıyla Meteoroloji Genel Müdürlüğünden Aydın (4 istasyon) ve Muğla (8 istasyon) illerine ait sıcaklık (maksimum, ortalama, minimum), yıllık ortalama yağış, ortalama nispi nem, ortalama rüzgâr hızı, hâkim rüzgâr yönü ve yüzdesini içeren uzun dönem iklim (1995-2017) verileri (MGM, 2018) alınmıştır. Elde edilen verilere göre çalışma alanı Emberger'e göre tipik Akdeniz iklimine sahiptir.

\subsection{Yöntem}

Öncelikle çalışma alanında yayılış gösteren endemik bitki taksonları ilgili literatür [Davis (19651985); Davis ve ark., 1988; Güner ve ark., 2000; Özhatay ve Kültür (2006); Özhatay ve ark., (1994, 1999, 2009, 2011, 2013, 2015 ve 2017)] taranmıştır.

2013-2017 yılları arasında gerçekleştirilen arazi çalışmaları sırasında: 807 noktadan 1955 adet bitki örneği toplanmış ve fotoğraflanmış; koordinatları, yükseltileri vb. mevkii özellikleri ile anakaya ve habitatları kaydedilmiş; alanın genel durumu ile alınan noktalarda gözlenen önemli bazı değişiklikler (inşaat, yol yapımı veya genişletilmesi ve yapılaşma gibi) not alınmış ve fotoğraflanmıştır.

Çalışma alanından toplanan örnekler Davis (19651985); Davis ve ark., (1988); Güner ve ark., (2000); Özhatay ve Kültür (2006); Özhatay ve ark., (1994, 1999, 2009, 2011, 2013, 2015 ve 2017) ve ilgili diğer literatür kullanılarak tayin edilmiş ve kayıt altına 
alınmıştır. Tayin edilen taksonların bulundukları IUCN kategorileri öncelikle "The IUCN Red List of Threatened Species" resmî sitesi (URL 2), "Tehdit Altında Bitki Türleri” sitesi (URL 6) ve Ekim ve ark., (2000) verileri karşılaştırılarak belirlenmiş ve değerlendirilmiştir. Bu türlerin CITES durumları ise Türkiye Bitkileri Veri Servisi (TÜBIVES) (URL 7) ve CITES türlerinin kontrol listesi sitelerinden (URL 8 ve URL 9) belirlenmiştir.

\section{Bulgular}

\section{1. Çalışma alanında tespit edilen endemik bitki taksonları}

Çalışma alanı ile ilgili literatür incelendiğinde yörede 316 adet endemik taksonun kaydedildiği görülmüştür. Gerçekleştirilen bu proje sonucunda Muğla OBM sınırları içinde yayılış gösteren 39 familya ve 132 cinse mensup toplam 368 adet endemik bitki taksonu tespit edilmiştir. Belirlenen bu taksonların IUCN durumları ve CITES kapsamı ayrıca incelenmiştir. Buna göre çalışma alanında tespit edilen endemik taksonların 321'inin IUCN değerine sahip olduğu (kalan 47 adet endemik taksonun belirlenmiş herhangi bir IUCN ulamı bulunmamaktadir) ve tespit edilen bu endemik taksonlardan 2 tanesinin ise CITES kapsamında yer aldığ1 görülmüştür.

\subsubsection{Endemik bitki taksonlarının familyalarına göre dağılımı}

Muğla OBM sınırlarında tespit edilen 39 familyaya mensup endemik bitki taksonlarının ait oldukları familyalar irdelendiğinde, 46 adet bitki taksonu ile Asteraceae en fazla takson içeren familyadır. $\mathrm{Bu}$ familyay1 Caryophyllaceae (45 takson), Lamiaceae (40 takson), Brassicaceae (32 takson), Scrophulariaceae (28 takson) ve Fabaceae (23 takson) familyalarının takip ettiği belirlenmiştir (Şekil 3). Çalışma alanında tespit edilen diğer 33 familyaya ait takson adedi 1 ila 17 arasında değişmektedir.

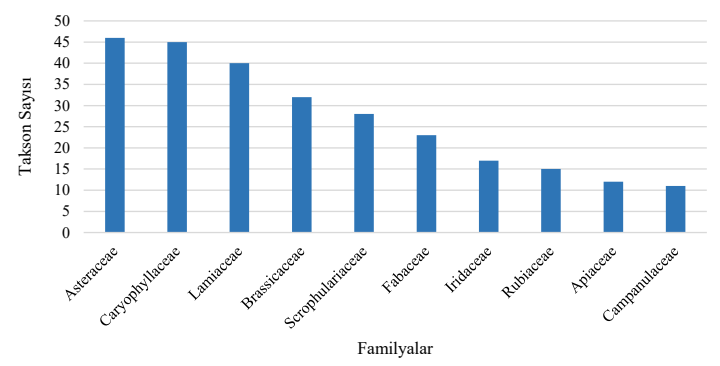

Şekil 3. Endemik bitki taksonlarının familyalarına göre dağılımı (ilk 10 Familya)

Figure 3. Distribution of endemic plant taxa according to their families (first 10 families)

\subsubsection{Endemik bitki taksonlarının cinslerine göre dağılımı}

Yapılan tespitlere göre Verbascum 23 takson, $\mathrm{Si}$ lene 15 takson, Crocus 13 takson, Alyssum ve Astragalus 12'şer takson ve Centaurea cinsi 11 adet taksonla temsil edilmektedir. Geriye kalan cinslerden 1 tanesi 9 takson, 3 tanesi 7 takson, 5 tanesi 6 takson, 3 tanesi 5 takson, 13 tanesi 4 takson, 15 tanesi 3 takson, 22 tanesi 2 takson ve 61 tanesi tek 1 takson ile temsil edilmektedir (Tablo 1).

Tablo 1. Takson sayılarına göre cinslerin dağılımı Table 1. Distribution of the genera according to the taxon numbers

\begin{tabular}{|c|c|}
\hline $\begin{array}{l}\text { Takson } \\
\text { Say1s1 }\end{array}$ & Cins \\
\hline 23 & Verbascum \\
\hline 15 & Silene \\
\hline 13 & Crocus \\
\hline 12 & Alyssum, Astragalus \\
\hline 11 & Centaurea \\
\hline 9 & Galium \\
\hline 7 & Allium, Campanula, Sideritis \\
\hline 6 & $\begin{array}{l}\text { Aperula, Hypericum, Minuartia, Muscari, } \\
\text { Salvia }\end{array}$ \\
\hline 5 & Asyneuma, Papaver, Veronica \\
\hline 4 & $\begin{array}{l}\text { Achillea, Alkanna, Anthemis, Arenaria, Col- } \\
\text { chicum, Ebenu,s Euphorbia, Ferulago, Fri- } \\
\text { tillaria, Helichrysum, Hesperis, Nepeta, Sc- } \\
\text { rophularia }\end{array}$ \\
\hline 3 & $\begin{array}{l}\text { Ballota, Bolanthus, Cirsium, Eremogone, Er- } \\
\text { yngium, Erysimum, Gypsophila, Iris, Linum, } \\
\text { Marrubium, Phlomis, Saponaria, Sedum, } \\
\text { Teucrium, Viola }\end{array}$ \\
\hline 2 & $\begin{array}{l}\text { Acantholimon, Amelanchier Aristolochia, } \\
\text { Cephalaria, Cerastium, Clinopodium, Cory- } \\
\text { dalis, Cyclamen Cytisus, Dianthus, Erodium, } \\
\text { Onopordum, Onosma, Ophrys, Origanum, } \\
\text { Ornithogalum, Prometheum, Rhaponticoides, } \\
\text { Stachys, Tanacetum, Tragopogon, Velezia }\end{array}$ \\
\hline 1 & $\begin{array}{l}\text { Aethionema, Ajuga, Alnus, Arenaria, Arme- } \\
\text { ria, Asphodeline, Aubrieta, Aurinia, Barbera, } \\
\text { Bilacunaria, Bufonia, Bupleurum, Carlina, } \\
\text { Colutea, Convolvulus, Cyanus, Cytisopsis, } \\
\text { Delphinium, Echinops, Erigeron, Gagea, } \\
\text { Genista, Geranium, Gladiolus, Globularia, } \\
\text { Hedysarum, Heldreichia, Helianthemum, } \\
\text { Iberis, Isatis, Juncus, Lamium, Laserpitium, } \\
\text { Matthiola, Micromeria, Noccaea, Nonea, } \\
\text { Omphalodes, Paronychia, Petrorhagia, Poly- } \\
\text { gonum, Pseudosempervivum, Pseudosemper- } \\
\text { vivum, Pterocephalus, Ptilostemon, Quercus, } \\
\text { Ranunculus, Ricotia, Rosularia, Salsola, Scil- } \\
\text { la, Scutellaria, Senecio, Spergularia, Ster- } \\
\text { nbergia, Thesium, Thlaspi, Thymus, Tordy- } \\
\text { lium, Trigonella, Turanecio, Valeriana }\end{array}$ \\
\hline
\end{tabular}




\subsubsection{Endemik bitki taksonlarının Bitki Coğrafyalarına göre dağılımı}

Çalışma alanında tespit edilen 368 adet endemik taksondan bir fitocoğrafya (bitki coğrafyası) elementi olanlarının toplam sayısı 278 adet olup; bu taksonların 45 adedi $(\% 11,96)$ Akdeniz, 4 adedi $(\% 1,1)$ Akdeniz (Dağ), 169 adedi $(\% 46,20)$ Doğu Akdeniz, 28 adedi $(\% 7,60)$ Doğu Akdeniz (Dağ), 31 adedi $(\% 8,42)$ İran-Turan ve 1 tanesi de $(\% 0,27)$ Karadeniz bitki coğrafyası elementidir. Geriye kalan 90 adedi $(\% 21,2)$ ise herhangi bir fitocoğrafya elementi olmayan veya bölgesi bilinmeyen taksonlardır (Şekil 4).

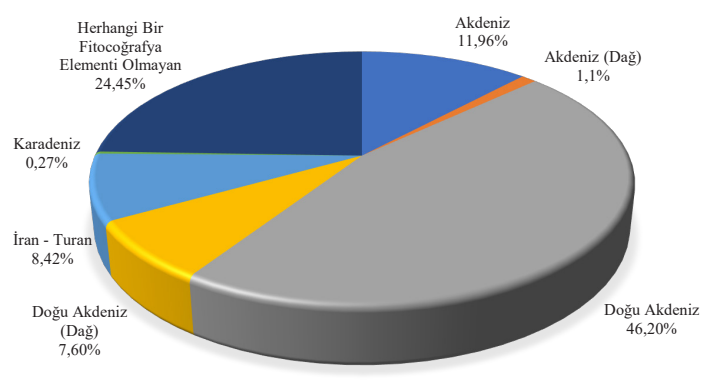

Şekil 4. Endemik bitki taksonlarının Bitki Coğrafyalarına göre dağılımı

Figure 4. Distribution of endemic plant taxa according to plant geographies

\subsubsection{Endemik bitki taksonlarının Kırmız Liste ulamlarına göre dağılımı}

Muğla OBM sınırlarında tespit edilen endemik bitki taksonlarının IUCN tehlike ulamları irdelendiğinde, 10 taksonun $(\% 2,98)$ kritik (CR), 55'inin $(\% 14,95)$ tehlikede $(\mathrm{EN}), 43$ 'ünün $(\% 11,68)$ hassas (VU), 57'sinin $(\% 15,49)$ korumaya tabii (CD), 49'inin $(\% 13,31)$ tehdite yakin (NT) ve 109'unun $(\% 29,9)$ asgari endişe altında (LC) olduğu görülmüştür. Yine bu taksonlardan 5'ine $(\% 1,35)$ ait yeterli veri olmadığı (DD) tespit edilmiştir. Geriye kalan 38 taksonun $(\% 10,32)$ ise k1rmiz1 liste kapsamında henüz bir tehlike ulamı bulunmamaktadır (Şekil 5).

\subsubsection{Endemik bitki taksonlarının yayılış gösterdikleri yükselti basamaklarına göre dağılımı}

Çalışma alanında tespit edilen taksonların bulunduğu yükseltilerin deniz seviyesinden 3.036 m'ye (Sandras Dağ́ zirvesi) kadar değiştiği görülmüştür. Söz konusu taksonların 0-300 m'ler arasında (198 noktada) 111 adet takson, 400-799 m'ler arasinda (78 noktada) 75 adet takson, 800-1.199 m'ler arasinda (94 noktada) 101 adet takson, 1.200-1.599 m'ler arasinda (153 noktada) 184 adet takson ve 1.600 ve üstü yükseltilerde (166 noktada) 231 adet taksonun yayılış gösterdiği belirlenmiştir (Şekil 6).

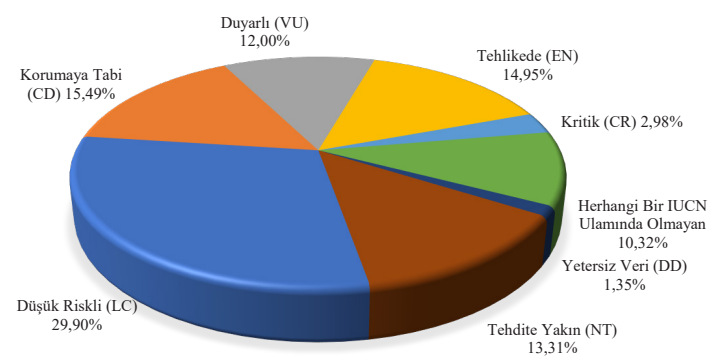

Sekil 5. Endemik bitki taksonlarının Kırmızı Liste ulamlarına göre dağılımı

Figure 5. Distribution of endemic plant taxa according to Red List results

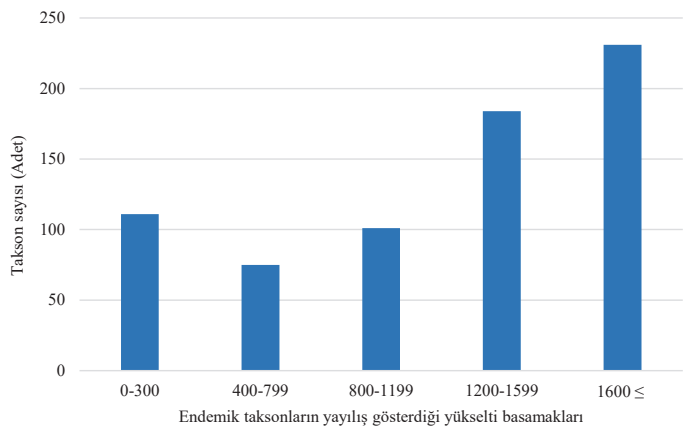

Şekil 6. Çalışma alanında tespit edilen taksonların bulunduğu yükselti basamakları

Figure 6. Distribution of endemic plant taxa according to elevation steps

\subsubsection{Endemik bitki taksonlarının yayılış gösterdikleri anakaya çeşitlerine göre dağılımı}

Çalışma sonunda elde edilen verilere göre alanda tespit edilen taksonların hangi anakaya/ana materyal üzerinde bulunduğu incelendiğinde oluşumlarına göre Sedimanter kayaçlar üzerinde 270 takson (Kireçtaşı: 262; Killi kireçtaşı: 23; Marn: 2; Kumtaş1: 7; Radyolarit: 1; Konglomera: 3), Metamorfik kayaçlar üzerinde 229 takson (Mermer: 1; Mikaşist: 33; Kuvarsşist: 22; Kalkşist: 7; Fillat: 17; Gnays: 13; Serpantin: 194), taşınmış ana materyal üzerinde 11 takson (Alüvyal: 2; Kolüvyal: 9) ve Magmatik kayaçlar üzerinde 7 taksonun (Metagranit: 6; Granit:1) yayılış gösterdikleri görülmüştür. (Şekil 7 ve Şekil 8).

Ayrıca çalışmada, 34 adet Serpantinofit (zorunlu serpantin bitkisi) ve 21 adet endemik takson Serpantinovag (hem serpantin üzerinde, hem de 
serpantin dışındaki farklı edafik koşullarda gelişebilen) takson kaydedilmiştir. Serpantinofit taksonlarından 3'ü, Serpantinovag taksonlardan ise 4'ü endemiklikten çıkarılmış türlerdir.

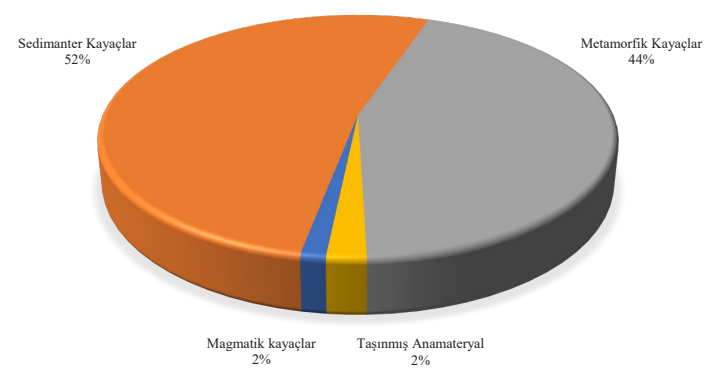

Şekil 7. Endemik bitki taksonlarının yayılış gösterdikleri ana materyal çeşitlerine dağ 1 lımı Figure 7. Distribution of endemic plant taxa by types of parent material

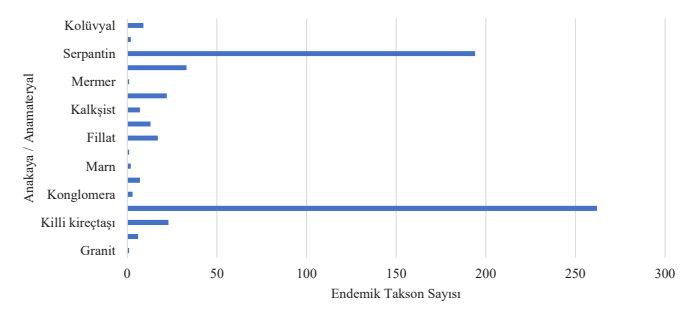

Şekil 8. Endemik bitki taksonlarının yayılıș gösterdikleri anakaya çeşitlerine göre dağ 11 mı 1 Figure 8. Distribution of endemic plant taxa by types of bedrock

\subsubsection{Endemik bitki taksonlarının CITES kapsamındaki durumu}

Muğla OBM sınırları içinde tespit edilen endemik taksonlardan 2 adedi CITES kapsamında bulunmaktadır: Cyclamen alpinum Dammann ex Spreng. (Syn: Cyclamen trochopteranthum O. Schwarz) ve Cyclamen mirabile Hildebr.'dir. Her iki takson da Doğu Akdeniz elementi olup adı geçen taksonlardan ilkinin IUCN ulamının asgari endişe, diğerinin ise tehlike altında olduğu görülmüştür (URL 5).

\subsubsection{Endemiklik ulamından çıkarılan taksonların genel durumu}

Ayrıca bu çalışmada Davis (1965-1988) ve Güner ve ark. (2000)'nda “endemik" olarak addedilen ancak, "Türkiye Bitkileri Listesi (Damarlı Bitkiler)" eserine göre endemiklikten çıkarılan (sadece Türkiye'de olmayıp bulunduğumuz kuzey-yarıkürede, yakın coğrafyada da yayılış gösterdiği belirlenen) ve son araştırmalara göre sinonim yapılmış (aynı kategoride kullanılan aynı taksonu ifade eden iki ya da daha fazla sayıdaki bilimsel isim) 29 familya ve 49 cinse mensup, toplam olarak 83 adet takson kaydedilmiştir (Güner ve ark., 2012).

$\mathrm{Bu}$ taksonların ait oldukları familyalar incelendiğinde 16 taksonla Lamiaceae familyasının başta geldiği görülmektedir. Bu familyayı 6'şar taksonla Asteraceae ve Fabaceaea familyaları ile 5'er taksonla Campanulaceae, Caryophyllaceae ve Scrophulariaceae familyaları takip etmektedir. Diğer familyalardan ise 1 ile 4 arasında taksonun endemiklikten çıkarıldığı belirlenmiştir.

Endemiklikten çıkarılan taksonların mensup oldukları cinsler dikkate alındığında ise Centaurea, Astragalus ve Thymus cinslerine ait 5'er, Campanula, Lamium ve Verbascum cinsine ait 4'er taksonun bulunduğu görülmüştür. Endemiklikten ç1karılan diğer cinslerin içerdiği takson sayısı 1 ila 3 takson arasında değişmektedir.

Yine endemiklikten çıkarılan bu taksonlardan 12 tanesi Akdeniz, 44 tanesi Doğu Akdeniz, 5 tanesi İran-Turan, 2 tanesi Doğu Akdeniz (Dağ) ve 1 tanesi Karadeniz fitocoğrafyası elementidir. Geriye kalan 21 adet takson ise herhangi bir fitocoğrafya elementi değildir.

Bahsi geçen bu taksonların 6 tanesi tehlikede (EN), 13 tanesi hassas (VU), 7 tanesi korumaya tabii (CD), 8 tanesi neredeyse tehdit altında (NT) ve 37 tanesi asgari endişe (LC) kırmızı liste ulamı içinde yer almaktadır. 12 taksonun ise henüz belirlenmiş bir ulamı bulunmamaktadır. Endemiklikten çıkarılan taksonlardan bir tanesi (Ophrys holoserica (Burm. fil) Greuter subsp. heterochila Renz \& Taubenheim) CITES kapsamında yer alırken iki tanesi ise (Aristolochia incisa Duchartre, Biarum tenuifolium (L.) Schott subsp. zeleborii (Schott) P. C. Boyce) nadir bulunan türlerdendir.

Bu taksonların 40 adedi 0-300 m, 30 adedi 400799 m, 35 adedi 800-1199 m, 39 adedi 1200-1599 m ve 42 adedi 1600 ve üstü yükseltilerde yayılış göstermektedir. Endemiklik ulamından çıkarılan bu taksonların yayılış gösterdikleri anakaya ve anamateryallerin oluşumları açısından yoğunlukla sedimanter kayaçlar olduğu görülmüştür. Bunu sırasıyla metamorfik kayaçlar, taşınmış ana materyal ve magmatik kayaçlar takip etmektedir.

\section{Tartışma ve Sonuç}

$\mathrm{Bu}$ çalışma sonucunda toplamda 39 familya ve 132 cinse mensup toplam 368 adet endemik takson kaydedilmiş ve çalışma alanı ile çevresinde yapılmış olan çalışmalar incelenerek belirlenen endemik (BET), endemiklikten çıkarılan takson- 
lar (EÇT) ve CITES kapsamında olan bu taksonlar derlenmiştir.

$\mathrm{Bu}$ araştırma ile Muğla OBM sınırlarında yayılış gösteren endemik taksonların güncel durumları belirlenmiştir. Genel olarak ifade edildiğinde endemik taksonların çoğunlukla Akdeniz bitki coğrafyası elementi oldukları, $1.600 \mathrm{~m}$ ve üstü yükseltilerde, sedimanter ve metamorfik anakayalar (özellikle kireçtaşları ve serpantinler) üzerinde yayılış gösterdikleri belirlenmiştir.

Muğla OBM sınırlarındaki endemik bitki taksonlarının güncel durumunun (Öner ve ark., 2018) incelendiği çalışma il bazında Aydın (Tablo 2) ve Muğla (Tablo 3) olmak üzere iki kısımda değerlendirilmiş ve bu yörede yapılan diğer çalışmaların sonuçları ile karşılaştırılmıştır.

Tablo 2. Aydın İlinde yapılan araştırmalar sonucunda tespit edilen taksonların karşılaştırmaları

Table 2. Comparison of the taxa determined in the Aydın Province

\begin{tabular}{lccc}
\hline Çalışmalar & $\begin{array}{c}\text { BET } \\
\text { takson } \\
\text { sayısı }\end{array}$ & $\begin{array}{c}\text { EÇT } \\
\text { takson } \\
\text { sayıs1 }\end{array}$ & $\begin{array}{c}\text { CITES } \\
\text { kapsa- } \\
\text { mindaki } \\
\text { takson } \\
\text { sayıs }\end{array}$ \\
\hline Çelik (1992) & 17 & 10 & \\
Çelik (1995) & 73 & 22 & \\
Gemici ve Oluk (1999) & 30 & 7 & 1 \\
Özel (1996) & 45 & 23 & 9 \\
Çilden (2011) & 34 & 15 & 2 \\
Aşıcı (2013) & 4 & - & 2 \\
Öner ve ark. (2018) & 89 & 27 & 12 \\
\hline
\end{tabular}

Aydın İli sınırları içinde kaydedilen taksonlar incelendiğinde endemik bitkilerden 19 adedi ve endemiklikten çıkarılmış taksonlardan 14 adedi Öner ve ark., (2018) ve yapılan diğer çalışmalarla ortaktır.

Çalışma alanı ile ilgili literatür taramasında bulunan başlangıç tür sayısı (316) ile çalışma sonucunda elde edilen tür sayısı (368) arasında belirgin bir fark vardır. Bunun öncelikli sebebi doğanın dinamikliği içerisinde özellikle bir yıllık (annual) olanlar başta olmak üzere, bitkilerin zaman içerisinde yer değiştirdiği ve farklı alanlara yayıldığ1dır (Gemici, 2001; Avcı, 2014). Bu nedenle çalışma sonuçlarının önceki çalışmalardan farklı olması olağandır. Öte yandan son yıllarda iklim ve yağış rejimlerinde meydana gelen değişiklikler bu farklılığı daha da arttırmış olabilir.

Yapılan bu çalışma bu dinamiklik içerisinde bir kesittir. Farklı zamanlarda yapılan farklı kesitlerin farklı sonuçlar vereceği de açıktır. Bu durum do- ğada meydana gelen bu tür değişikliklerin sürekli izlenmesi ve belirli zamanlarda kaydedilmesini zorunlu kılmaktadır. Ayrıca bilimsel gelişmelerin ve araştırmaların ışığında yapılan incelemeler sonucunda taksonların günümüz değerlendirmeleri yeniden düzenlenmektedir. Yeni türlerin/taksonların tanımlanması söz konusu olduğu gibi tanımlanmış olan türler/taksonlar birleştirilebilir ve tek bir tür/takson olabilir ve/veya endemiklik özellikleri, IUCN ulamları ve CITES kapsamında bulunup bulunmamaları değişebilir.

Tablo 3. Muğla İlinde yapılan araştırmalar sonucunda tespit edilen taksonların karşılaştırmaları

Table 3. Comparison of the taxa determined in the Muğla Province

\begin{tabular}{lccc}
\hline Çalışmalar & $\begin{array}{c}\text { BET } \\
\text { takson } \\
\text { sayıs1 }\end{array}$ & $\begin{array}{c}\text { EÇT } \\
\text { takson } \\
\text { sayıs1 }\end{array}$ & $\begin{array}{c}\text { CITES } \\
\text { kapsamında } \\
\text { takson sayıs1 }\end{array}$ \\
\hline Özhatay (1981) & 49 & 12 & 5 \\
Güner ve ark. (1996) & 78 & 16 & 9 \\
Körüklü (1997) & 42 & 22 & 7 \\
Yerli (2001) & 62 & 16 & 14 \\
Varol ve ark. (2004) & 64 & 24 & 5 \\
Pirhan (2003) & 10 & 1 & 3 \\
Kaya (2004) & 31 & 15 & - \\
Aktaş Aytepe ve & 38 & 17 & 3 \\
Varol (2007) & 16 & 7 & - \\
Şenol (2006) & 27 & 4 & - \\
Çetin ve Seçmen & & & \\
(2008) & 86 & 14 & 2 \\
Pirhan (2010) & 13 & 6 & 8 \\
Çınar (2010) & 40 & 13 & 4 \\
Kırdal (2011) & & 9 & 1 \\
Güler ve Varol & 18 & 9 & 12 \\
(2012) & & & \\
Ceylan (2014) & 32 & 22 & 7 \\
Öz (2014) & 47 & 16 & 4 \\
Şenol ve ark. (2010) & 14 & 7 & 28 \\
Öner ve ark. (2018) & 339 & 84 & \\
\hline & & & \\
\hline
\end{tabular}

Nitekim bu çalışmada Muğla İli sınırları içinde kaydedilen taksonlar arasında ortak olarak 159 adet endemik ve 53 adet endemiklikten çıkarılmış takson belirlenmiştir. Yine çalışma alanında, son yıllarda yapılan araştırmalar sonucu bulunan ve tanımlanan yeni ve endemik 5 adet takson [Muscari serpentinicum (Pirhan ve ark., 2014), Muscari elmasii (Yıldırım, 2016), Lamium bilgililii (Celep, 2017), Crocus heilbronniorum (Erol ve ark., 2018), Muscari muglaensis Eker ve ark., 2020)] kaydedilmiştir. Kaydedilen bu taksonlardan 2 tanesi CITES kapsamında olup ticareti yasaktır.

Araştırma sırasında Aydın ve Muğla illeri için yeni kayıt olduğu belirlenen toplam 76 adet ende- 
mik takson kaydedilmiş olup bu çalışma ile diğer araştırmalar arasındaki en belirgin farktır. Söz konusu bu yeni kayıtlar Şenkul ve Kaya (2017)'nın Türkiye'de yayılış gösteren endemik bitkilerin yayılışları ile ilgili makalelerinde yaptıkları tespitle uyumludur. Yazarlar merkezi eğilim ölçümlerinin mekânsal dağılımına göre Türkiye'nin endemik taksonlarının dağılımlarını analiz etmişlerdir. Bahsi geçen çalışmada endemik bitkilerin konumuna ait yer, yön, mesafe ve yükselti gibi bilgiler derlenmiş ve endemik taksonların ortalama merkezinin bu merkezin güneybatısında kalan NevşehirMerkez civarında olduğu ifade edilmiştir. Bu bilgi doğrultusunda Türkiye haritası üzerinde lokasyonları belirlenen endemik bitki taksonlarının medyan merkezlerinin ortalama merkezin güneyinde yer aldığı belirtilmiştir. Endemik taksonların standart sapma elipsiyle dağılımının uzanımının belirlenebileceğini söyleyen yazarlar Türkiye endemik taksonlarının yayılışlarının Türkiye'nin geometrik şekline bağlı olarak kuzeydoğu-güneybatı eksenli olduğunu ortaya çıkarmışlardır. Çalışma sonucunda elde edilen yeni kayıtlar Şenkul ve Kaya (2017)'nın bulguları ile doğru orantılı olup yazarların ortaya koyduğu bu sonuç, çalışma alanımızda kuzey-kuzeydoğu ve doğu yayılışlı taksonların bulunmasını açıklar niteliktedir.

Çalışma alanında tespit edilen endemik taksonların fitocoğrafik bölgelere göre dağılımları ayrıca incelenmiştir. Buna göre çalışma alanı Akdeniz Flora Bölgesi içerisinde yer aldığından kaydedilen taksonların büyük bölümü Akdeniz (Akdeniz, Akdeniz Dağ, Doğu Akdeniz ve Doğu Akdeniz Dağ) elementidir. Doğal olarak İran-Turan ve Karadeniz elementlerinin oranı oldukça düşüktür. Yörenin tipik bir Akdeniz İklim Bölgesi olması bu sonucu doğurmaktadır.

Çalışma sonucunda kaydedilen endemik takson sayısı (368), Eken ve arkadaşlarının (2006) belirlediği endemik bitkilerin bölgesel dağılımı ile karş1laştırıldığında oldukça dikkat çekici bir değere sahiptir. Buna göre Akdeniz Bölgesinde tanımlanan endemik takson sayısı 862, Ege Bölgesinde ise 171 adettir. Bu durumda çalışma alanının 368 adet endemik taksonun yayılış alanı olması endemizmin oldukça yüksek olduğunu göstermektedir.

Gemici ve Şık (1992) yükselti basamağ olarak endemiklerin en yaygın olduğu yükselti aralığının 1.000-2.000 m arasında olduğunu belirtmişlerdir. Ülkemiz endemiklerinin \%80'i bu yükseltiler arasında yayılış göstermektedir. Çalışma alanımız yükselti açısından incelendiğinde, endemik taksonların en yoğun bulunduğu yükselti basamağ 231 taksonun yayılış gösterdiği $1.600 \mathrm{~m}$ ve üstüdür. Bunu 184 takson ile 1.200-1599 m arasında- ki yükselti basamağı takip etmektedir. 0-300 m yükselti basamağındaki endemik takson sayısı ile 800-1.199 m yükselti basamağında yayılış gösteren endemik takson sayısı hemen hemen aynıdır. Buradaki yakın sonucun nedeni bu iki yükselti basamağında alınan nokta sayıları arasındaki fark olabilir. 0-300 m yükselti basamağında alınan nokta sayısı 800-1.199 $\mathrm{m}$ arasında alınan nokta sayısının iki katıdır (198/94). Dolayısı ile bu çalışmada yükselti basamağına ilişkin veriler adı geçen yazarların bulgularıyla örtüşmektedir.

Gemici ve ark., (1992) endemizm oranı ile kayaç yapısı arasında yakın bir ilişki bulunduğunu ifade etmişlerdir. Çalışmamıza göre, özellikle serpantin anakayaların bu bakımdan oldukça dikkat çektiği, Anadolu'da bu tip kayaların bir hayli yaygın olduğu ve endemizmin yüksek olduğu bölgelerin önemli bir bölümünde bu kayaların yayılış gösterdiği görülmüştür. Çalışma alanı anakaya bakımından incelendiğinde endemik taksonların en yoğun olduğu kayaçların toplamda 270 adet taksonla sedimanter kayaçlar olduğu belirlenmiştir. Yine bu kayaçlar içinde kireçtaşı anakayanın 262 adet taksonla ilk sırada olduğu görülmektedir. Bunu toplamda 229 takson ile metamorfik kayaçlar ve bu grup içinde 194 adet endemik taksonla öne çıkan serpantin anakaya izlemektedir. Araştırma alanında gözlenen diğer magmatik anakayaya ve taşınmış anamateryallere sahip alanlarda endemik takson sayısı oldukça düşmektedir. Çalışma alanında sedimanter kayaç üzerinde yayılış gösteren endemik takson sayısının metamorfik kayaç üzerinde yayılış gösterenlerden daha fazla olması her ne kadar Gemici ve ark. (1992) sonuçları ile uyumlu görünmese de bunun sebebi, sedimanter anakaya yapısında olan inceleme alanının büyüklüğünden kaynaklanabilir. Nitekim çalışma alanının büyük bir kısm1, özellikle endemik taksonların daha yoğun yayılış gösterdiği yüksek dağ habitatlarının çoğunluğu, sedimanter kayaçlar ve özellikle kireçtaşı üzerindedir.

Ülkemizin edafik, jeolojik, joeomorfolojik ve topoğrafik yapısındaki çeşitliliği flora çeşitliliğinin de önemli nedenlerinden birisidir. "Jeolojik izolasyon" olarak adlandırılan ve sıra dışı ekolojik koşullara sahip jips ve serpantin gibi kayaçlardan oluşan topraklarda endemizmin yüksek olduğu alanlar “jeolojik ada" ya da "edafik ada" olarak tanımlanır (Avc1, 2005). Adıgüzel ve Reeves (2012) endemizm merkezi olan 28 serpantin bölgesi içinde Sandras Dağı (Muğla)'nın en önemli serpantin endemik alanı olduğunu açıklamışlar ve Marmaris, Marmaris-Datça, Köyceğiz ve Fethiye-Köyceğiz'in bölgedeki diğer önemli serpantin bölgeleri olduklarını ifade etmişlerdir. Çalışma alanında yayılış 
gösterdiği görülen 34 adet Serpantinofit ve 21 adet Serpantinovag takson nedeniyle çalışma alanının bu kısmının (Sandras Dağı, Marmaris, Marmaris-Datça, Köyceğiz ve Fethiye-Köyceğiz)' “edafik ada" olduğu söylenebilir.

Çalışma alanında belirlenen endemik taksonların IUCN kırmızı liste ulamları "kritik tehlikede" ile "herhangi bir ulama sahip olmayan" arasında değişmektedir. Çalışma sonucunda belirlenen taksonların, özellikle herhangi bir ulama sahip olmayanların, tehlike kategorilerinin günümüz koşulları dikkate alınarak yeniden değerlendirmesi uygun olacaktır.

Çalışma alanı gerek biyolojik çeşitlilik, gerek endemizm ve gerekse jeolojik açıdan son derece özellikli ve önemli bir alandır. Bu nedenle; öncelikle sahip olduğu endemik takson varlığı, tescillenmiş özel statülü alanları (10 adet Önemli Bitki Alanı, 18 adet Önemli Doğa Alanı, 18 adet Bitki Çeşitlilik Merkezi, 5 adet Özel Çevre Koruma Bölgesi ve 2 adet Sicak Nokta), endemizm merkezi olan 28 serpantin bölgesinden birine (Sandras Dağı) ve yine edafik ada potansiyeline sahip (Marmaris, Marmaris-Datça, Köyceğiz ve Fethiye-Köyceğiz) alanları göz önünde bulundurularak sırasıyla Sandras Dağ1, Erendağı, Fethiye-Babadağ ve Datça Yarımadası acilen özel bir koruma statüsüne kavuşturulmalıdır.

Bölgedeki özellikli alanlarda insan kullanımları en aza indirilmeli ve mümkünse kaldırılmalı, 1.000 m ve üstü yükselti basamaklarında ve serpantin anakayanın bulunduğu alanlarda bu takson ve habitatlar için izleme programları oluşturulmalı ve buralarda ormancılık faaliyetlerinin etkisi incelenmeli, gerekirse habitatı ve türü/türleri korumak için zonlama yapılmalıdır.

Muğla OBM öncülüğünde ilgili personel ve yöre halkı biyolojik çeşitlilik ve koruma-izleme konularında bilgilendirilmeli, etkin izleme ve koruma düzenlemeleriyle ilgili doğadan bitki toplanması ve biyolojik kaçakçılığa karşı uyarı, eğitim ve katılım programları yapılmalıdır.

Yöre halkının orman üzerindeki baskısını azaltıcı sosyo-ekonomik çözümler ile öncelikli taksonların biyolojileriyle ve popülasyon büyüklükleriyle ilgili bilimsel çalışmalar yapılmalı ve korunması gereken asgari popülasyon büyüklüğü belirlenmelidir. Ayrıca bu taksonların ekolojik istekleri belirlenmeli ve özellikle "Tehlikede" kategorisinde olanların yaygınlaştırılması olanakları araştırılmalıdır.

\section{Teşekkür}

Bu makale Orman Genel Müdürlüğü, Ege Ormancılık Araştırma Enstitüsü Müdürlügüunce yürütül- müş olan “Muğla Orman Bölge Müdürlüğü’ndeki Endemik ve Nadir Taksonların Güncel Durumunun Belirlenmesi" isimli araştırma projesi kapsamında hazırlanmıştır. Bu bağlamda kurumlara ve arazi çalışmaları sırasında yardımlarını esirgemeyen gönüllü doğaseverler Rifat ÖZDEMİR, Bülent ELMAS ve Riyat GÜL'e teşekkür ederiz.

\section{Kaynaklar}

Adıgüzel, N., Reeves, R. D., 2012. Important serpentine areas of Turkey and distribution patterns of serpentine endemics and nickel accumulators. Bocconea 24: 7-17. 2012. ISSN 1120-4060

Akkemik, Ü. (Yay. Haz.), 2014. Türkiye'nin Doğal-Egzotik Ağaç ve Çalılar1-1. T.C. Orman ve Su İşleri Bakan11 ̆ğ, Orman Genel Müdürlüğü, ISBN: 978-605-4610-488, 736 s., Ankara.

Aktaş Aytepe, H., Varol, Ö., 2007. Bencik Dağ1 (Yatağan-Muğla) Floras1, Ekoloji, 16(63): 41-61.

Meteoroloji İşleri Genel Müdürlüğü (MGM), 2018. Aydın ve Muğla İlleri Uzun Dönem (1995-2017) İklim Verileri, Ankara.

Aș1c1, O., 2013. Aydın Șehir Florası. Adnan Menderes Üniversitesi Fen Bilimleri Enstitüsü, Biyoloji Anabilim Dalı, Yüksek Lisans Tezi, 131 s., Aydın.

Avcı, M., 2005. Çeşitlilik ve Endemizm Açısından Türkiye'nin Bitki Örtüsü. İstanbul Ünv. Edb. Fak. Coğ. Böl. Coğrafya Dergisi, 13: 27-55, İstanbul.

Avc1, M., 2014, Paleocoğrafya, Resimli Türkiye Floras1, Nezahat Gökyiğit Botanik Bahçesi Yayınları, Flora Dizisi 2, Türkiye İş Bankası Kültür yayınları, Genel Yayın No: 3090).

Celep, F., 2017. Lamium bilgilii (Lamiaceae), a new species from South-western Turkey (Burdur-Muğla). Phytotaxa, 312(2): 263-270.

Ceylan, O., 2014. Kavaklıdere (Muğla) Florası. Muğla Sitk1 Koçman Üniversitesi, Fen Bilimleri Enstitüsü, Biyoloji Anabilim Dalı, Doktora Tezi, 158 s., Muğla.

Çelik, A., 1992. Karıncalı Dağı (Nazilli) Florası. Ege Üniversitesi Fen Bilimleri Enstitüsü, Biyoloji Ana Bilim Dalı, Yüksek Lisans Tezi, 56 s., İzmir.

Çelik, A., 1995. Aydın Dağlarıının (Aydın) Flora ve Vejetasyonu. Ege Üniversitesi, Fen Bilimler Enstitüsü Biyoloji Anabilim Dalı, Doktora Tezi, 143 s., İzmir.

Çetin, E., Seçmen, Ö., 2008. Flora of Boncuk Mountains (Burdur-Muğla, Turkey). International Journal of Botany, 4(2): 130-150.

Çınar, H., 2010. Aspat (Strabilos) Kalesi ve Çevresinin Floristik Özellikleri. Muğla Üniversitesi, Fen Bilimleri Enstitüsü, Biyoloji Anabilim Dalı, Yüksek Lisans Tezi, 142 s., Muğla. 
Çilden, E., 2011. Paşa Yaylası (Aydın) Florası ve Etnobotanik Özellikleri. Hacettepe Üniversitesi, Biyoloji Anabilim Dalı, Yüksek Lisans Tezi, 173 s., Ankara.

Davis, P. H., 1965. Flora of Turkey and the East Aegean Island. Vol. 1, Edinburgh University Press, Edinburgh.

Davis, P. H., 1965-1985. Flora of Turkey and the East Aegean Island. Vol. 1-9, Edinburgh University Press, Edinburgh.

Davis, P.H., Mill, R.R., Tan, K. (Eds.), 1988. Flora of Turkey and the East Aegean Islands. Vol. X, Edinburgh University Press, Edinburgh.

Eker, İ, Duman, H. ve Yıldırım, H., 2020. Muscari muglaensis (Asparagaceae, Scilloideae), a new species from southwestern Anatolia, Phytotaxa 475 (4): 267-278.

Eken, G., Bozdoğan, M., İsfendiyaroğlu, S., Kılıç, D. T., Lise, Y. (Yay. haz.) 2006. Türkiye'nin Önemli Doğa Alanlar1 I, ISBN: 978-975-98901-3-1 (1 C). Doğa Koruma Derneği. Ankara.

Ekim, T., Koyuncu, M., Vural, M., Duman, H., Aytaç, Z., Adıgüzel, N., 2000. Türkiye Bitkileri Kırmızı Kitabı, Eğrelti ve Tohumlu Bitkiler (Red Data Book of Turkish Plants. Pteridophyta and Spermatophyta), Türkiye Tabiatını Koruma Derneği yayını, Barışcan Ofset, Ankara.

Ekim, T., 2014. Damarl1 Bitkiler, Güner, A., Ekim, T. (Yay. haz.), Resimli Türkiye Florası, Cilt I., Nezahat Gökyiğit Botanik Bahçesi ve Flora Araştırmaları Derneği Yayınları. Flora Dizisi 2. Türkiye İş Bankası Kültür Yayınları, Genel Yayın No: 3090. İstanbul syf. 159-162.

Erol O., Harpke, D., Çiftçi, A., 2018. Crocus heilbronniorum, a new Turkish species of Series Lyciotauri (Iridaceae). Phytotaxa, 298(2): 173-180.

Ersoy, Ş., 1990. Batı Toros (Lîkya) Naplarının Yapısal Öğelerinin ve Evriminin Analizi. Istanbul Ünv. Müh Fak. Jeo. Müh. Dergisi, 37: 5-16, İstanbul.

Gemici, Y., 1999. Biyoçeşitlilik ve Bitki Genetik Kaynakları (Ders Notları), Ege Ünv. Fen Fak. Biyoloji Bölümü., İzmir.

Gemici, Y., 2001. Bitki Coğrafyası Ders Notları. Ege Ünv. Fen Fak. Biyoloji Bölümü, 117 s. Bornova, İzmir.

Gemici, Y., Ş1k, L., 1992. Türkiye Florasında Ende-

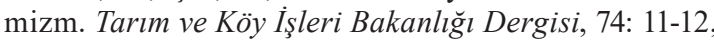
Ankara.

Gemici, Y., Oluk, S., 1999. Babadağ (Denizli)'1n Flora ve Vejetasyonu. Türkiye Bilimsel ve Teknik Araştırma Kurumu, Temel Bilimler Araştırma Gurubu, Proje No: TBAG-1387 (195T022), İzmir.

Gemici Y., Seçmen, Ö., Ekim, T., Leblebici, E., 1992. Türkiye'de Endemizm ve İzmir Yöresinin Bazı Endemikleri, Ege Ünv. Coğrafya Dergisi, 6: 61-84, İzmir.

Geray, U., Akesen, A., 2001. Av ve Yaban Hayatı Kaynaklarının Sürdürülebilir Yönetimi. Sürdürülebilir Av- cılık İçin Temel Eğitim Kitabı, T.C. Orman Bakanlı̆̆ı, Milli Parklar ve Av-Yaban Hayatı Genel Müdürlüğü, Eğitim Yayınlar1-1, ISBN: 975-8273-32-9, ISSN: 9758273-32-9, Sayfa: 75-152, Başak Matbaacılik, Ankara.

Güler, B., Varol, Ö., 2012. Floristic structure of historical Labranda ruins and its surroundings (Milas, Muğla/ Turkey). Biological Diversity and Conservation (ISSN 1308-8084 Online), 5(3): 54-68

Gülsoy, S., Özkan, K., 2008. Tür Çeşitliliğinin Ekolojik Açıdan Önemi ve Kullanılan Bazı İndisler. Süleyman Demirel Üniversitesi Orman Fakültesi Dergisi, ISSN: 1302-7085, Seri A, 1: 168-178.

Güner, A., Vural, M., Duman, H., Dönmez H., Sağban, H., 1996. The flora of the Köyceğiz-Dalyan Specially Protected Area (Muğla-Turkey). Turkish Journal of Botany, E-ISSN: 1303-6106, 20(4): 329-372.

Güner, A., Özhatay, N., Ekim, T., Başer, H. C., 2000. Flora of Turkey and the East Aegean Island. Vol. XI, Supplement 2, 656 p., Edinburgh University Press, Edinburgh.

Güner, A., Aslan, S., Ekim, T., Vural, M., Babaç, M.T. (Edlr.), 2012. Türkiye Bitkileri Listesi (Damarlı Bitkiler). Nezahat Gökyiğit Botanik Bahçesi Yayınları, Flora Dizisi: 1, ISBN: 978-605-604-25-7-7, 1290 s., İstanbul.

Kaya, E., 2004. Muğla (Merkez) Florası. Muğla Üniversitesi Fen Bilimleri Enstitüsü, Biyoloji Anabilim Dalı, Yüksek Lisans Tezi, 130 s., Muğla.

Kırdal, Y., 2011. Masa Dağ1 ve Kızıldağ (Muğla) Floras1. Muğla Üniversitesi Fen Bilimleri Enstitüsü, Biyoloji Ana Bilim Dalı, Yüksek Lisans Tezi, 144 s., Muğla.

Körüklü, T.S., 1997. Babadağ (Fethiye-Muğla) Florası. Ankara Üniversitesi Fen Bilimleri Enstitüsü, Biyoloji Anabilim Dalı, Yüksek Lisans Tezi, 103 s. Ankara.

Öner, H., H., Özel, N., Altun., Yanmadık, Y., Şafak., İ., 2018. Muğla Orman Bölge Müdürlüğü'ndeki Endemik ve Nadir Taksonların Güncel Durumunun Belirlenmesi. Proje No: 15.6308.

Öz, U., 2014. Kurukümes Dağ1 (Milas-Muğla) Floras1. Muğla Sitk1 Koçman Üniversitesi Fen Bilimleri Enstitüsü, Biyoloji Anabilim Dalı, Yüksek Lisans Tezi, 139 s., Muğla.

Özel, N., 1996. Beşparmak Dağları ve Dilek Yarımadası Milli Parkı Bitki Örtüsü Üzerine Araştırmalar. Ege Ormancılık Araştırma Enstitüsü Müdürlügüu, Orman Bakanlığg1 Yayın No: 021, Enstitü Müdürlüğü Yayın No: 1, Teknik Bülten No: 1, ISSN: 1300-9508, İzmir.

Özhatay, E., 1981. Sandras Dağı'nın (Muğla) Bitkisel Örtüsü ve Bazı Endemik Türleri Üzerinde Palinojik, Sitolojik Araştırmalar. Matematik, Fiziki ve Biyolojik Bilimler Araştırma Grubu, Proje No: TBAG-306, İstanbul.

Özhatay N., Byfield, A., Atay, S., 2003. Türkiye'nin Önemli Bitki Alanlar1, ISBN: 975-92433-0-x, WWF Türkiye (Doğal Hayatı Koruma Vakfı) İstanbul.87 s. 
Özhatay, N., Kültür, Ş., 2006. Checklist of additional taxa to the supplement Flora of Turkey III. Turkish Journal of Botany, 30: 281-316.

Özhatay, N., Kültür, Ş., Aksoy, N., 1994. Check-list of additional taxa to the Supplement Flora of Turkey. Turkish Journal of Botany., 18: 497-514.

Özhatay, N., Kültür Ş., Aksoy, N. 1999. Checklist of additional taxa to the supplement Flora of Turkey II. Turkish Journal of Botany, 23: 151-169.

Özhatay. N, Kültür Ş., Aslan S., 2009. Checklist of additional taxa to the supplement Flora of Turkey IV. Turkish Journal of Botany, 33: 191-226.

Özhatay, F. N., Kültür, Ş., Gürdal, M.B., 2011. Checklist of additional taxa to the supplement Flora of Turkey V. Turkish Journal of Botany., 35: 589-624.

Özhatay, N., Kültür, Ş., Gürdal, B., 2013. Checklist of additional taxa to the supplement Flora of Turkey VI. İstanbul Eczacılık Fakültesi Dergisi, 43 (1): 33-82.

Özhatay, N., Kültür, Ş., Gürdal, B., 2015. Checklist of additional taxa to the supplement Flora of Turkey VII. Istanbul Eczacılık Fakültesi Dergisi, 45(1): 61-86.

Özhatay, N., Kültür, Ş., Gürdal, B., 2017. Checklist of additional taxa to the supplement Flora of Turkey VIII. İstanbul Eczacılık Fakültesi Dergisi, 47 (1): 30-44.

Pirhan, A.F., 2003. Didim, Milas, Ören Arasında Kalan Bölge Floras1. Ege Üniversitesi Fen Bilimleri Enstitüsü, Biyoloji Anabilim Dalı, Yüksek Lisans Tezi, 62 s., İzmir.

Pirhan, A.F., 2010. Akdağ (Fethiye) Flora ve Vejetasyonu. Ege Üniversitesi Fen Bilimleri Enstitüsü, Biyoloji Anabilim Dalı, Doktora Tezi, 127 s., İzmir.

Pirhan, A. F., Yıldırım, H., Altığlu, Y., 2014. Muscari serpentinicum spp. nova (Asparagaceae): a new species from western Anatolia, Turkey. Ot Sistematik Botanik Dergisi, Cilt 21 Say1 1.Syf: 1-14. ISSN 1300-2953.
Senol, S.G., 2006. Güney Ege Denizi (Ceşme-Antalya Aras1) Adalar1 Flora ve Vejetasyonu. Ege Üniversitesi Fen Bilimleri Enstitüsü, Biyoloji Anabilim Dalı Bilim Dalı, Doktora Tezi, 159 s., İzmir.

Şenol, S.G., Y1ldırım, H., Pirhan, A.F., 2010. Kelebekler Vadisi (Ölüdeniz-Fethiye) Florası. Ot Sistematik Botanik Dergisi, 17(2): 121-140.

Şenkul, Ç., Kaya, S., 2017. Türkiye Endemik Bitkilerinin Coğrafi Dağılıș1. Türk Coğrafya Dergisi, 69: 109120.

URL 1. https://www.resmigazete.gov.tr/arsiv/22672.pdf (24.10.2018)

URL 2. http://www.iucnredlist.org (22.03.2019)

URL 3. https://www.ogm.gov.tr/ekutuphane (19.11.2019)

URL 4. https://muglaobm.ogm.gov.tr/Sayfalar/Ormanlarimiz/OrmanVarligi.aspx (19.11.2019).

URL-5 https://ockb.csb.gov.tr/ (31.07.2019)

URL 6 www.tehditaltindabitkiler.org.tr (31.07.2019)

URL 7 http://www.tubives.com/ (31.07.2019)

URL 8. http://checklist.cites.org (22.03.2019)

URL 9 https://www.unep-wcmc.org/resources-and-data/checklist-of-cites-species (22.03.2019)

Varol, Ö., Doğru, A., Kaya, E., 2004. Y1lanlı Dağ1 (Muğla)'nın Florası. Ekoloji, 13(50): 23-36.

Yerli, S.V. (Editör), 2001. Datça Bozburun Özel Çevre Koruma Bölgesi Biyolojik Zenginliğinin Tespiti ve Yönetim Planı. Çevre Bakanlığ 1 Özel Çevre Koruma Kurumu Başkanlığı Yayını, 261 s., Ankara.

Y1ldırım, H., 2016. Muscari elmasii spp. nova (Asparagaceae): a new species from western Anatolia. Turkey. Turk J Bot (2016) 40: 380-387. 